\title{
Seasonal abundance of the demersal copepod Pseudodiaptomus cokeri (Calanoidea: Pseudodiaptomidae) in a Caribbean estuarine environment
}

\author{
Eduardo Ríos Jara ${ }^{1}$ \\ 1 Labcratorio de Ecosistemas Marinos y Acuicultura. Departamento de Ecología. Centro Universitario de Ciencias Biológicas \\ y Agropecuarias. Universidad de Guadalajara. Apartado Postal 52-114, Zapopan 45030. Jalisco, México. Telfax (52) (3) \\ 682-0076. E-mail : edurios@cucba.udg.mx
}

Received 15-X-1997. Corrected 8-VI-1998. Accepted 18-VI-1998.

\begin{abstract}
Seasonal abundance variations of the demersal copepod Pseudodiaptomus cokeri were examinated at three locations (center, north shore and south shore) in Phosphorescent Bay, Puerto Rico, throughout an annual cycle. Nocturnal oblique tows (21:00-23:00 hr) were taken biweekly (three replicates) at each location with a conical net (mouth diameter $=0.5 \mathrm{~m}$; mesh size $=135 \mu \mathrm{m}$ ) and a standard calibrated flowmeter. Water temperature and salinity measurements were taken at the surface and near the bottom in each location before towing activities using a SCT meter. Chlorophyll-a concentrations were fluorometrically determined. The adult and copepodite stages of this species accounted for approximately $1.6 \%$ of the annual mean total zooplankton abundance of the bay. Higher abundance of $P$. cokeri (mean $\pm 1 \mathrm{SD}=4191 \pm 1444$ individuals $\mathrm{m}^{-3}$ ) was associated with cool water temperatures and dry conditions (cool/dry season) which prevailed between December and March relative to the period between April and November (warm/wet season) with lower abundance. Fluctuations of this population followed progressive increments in chlorophyll-a concentrations at the three sampling stations (One-way ANOVA, $\mathrm{p}<0.05$ ). However, abundance was generally higher on the north shore of the bay (Tukey's test, $\mathrm{p}<0.05$ ). Differences in abundance of $P$. cokeri between sampling stations could be related to the different types of substratum found in the bay. Apparently, this species prefers areas with heterogeneous substrata. Its demersal behavior may contribute to the observed distribution inside the bay.
\end{abstract}

Key words: Demersal, copepod, population variations, zooplankton, Caribbean estuary.

Substantial attention has been devoted to descriptions of the spatial and temporal distribution patterns of zooplankton in nearshore environments of Puerto Rico (Coker and González 1960, Suárez-Caabro and Shearls 1972, Youngbluth 1976, 1979, Pesante 1979, Zayas 1979, Rojas and Suárez-Caabro 1979, Youngbluth 1980, Yoshioka et al. 1985, García and López 1989, García and Durbin 1993). These studies give information about the physical and biological factors that regulate the development and persistence of these communities. Most of the plankton research in Puerto Rico, however, has been focused at the community level; studies on the ecology of particular populations are few and limited to copepod species of the genus Acartia (González 1980, Olivieri-Vega 1987, Santiago 1988).

Among the characteristic zooplankters of the coastal waters of Puerto Rico is the calanoid 
copepod Pseudodiaptomus cokeri González and Bowman 1965. This species was first collected in Phosphorescent Bay in 1957, and described later by González and Bowman (1965). It has been subsequently reported in collections from several bays along the southern coast of the island as Jobos Bay (Youngbluth 1980) and the Guayanilla and Tallaboa Bays (Rojas and Suárez-Caabro 1979). This copepod is resident inside these bays, and it was not found in adjacent neritic waters. Pseudodiaptomus cokeri has been reported also from Jamaica, Puerto Rico, Antigua and St. Lucia (González and Bowman 1965), Trinidad (Bacon 1971), the Atlantic coast of the Canal Zone (Bowman 1978), Venezuela, Panama and Belize (Walter 1989), and Cuba and the Gulf of México (Campos and Suárez-Morales 1994).

The demersal species of the genus, including $P$. cokeri, tend to remain near, on or in the bottom during the day, but rise towards the water column at night (González and Bowman 1965, Bowman 1978). Demersal zooplankters are usually undersampled by traditional plankton tows performed during daytime. This may be the reason why most studies do not report and possibly underestimate the abundance of Pseudodiaptomus cokeri in Caribbean embayments, including Puerto Rico. Recent plankton studies using nocturnal tows, emergence traps or diver-towed nets near the bottom have produced new information on the abundance and distribution of demersal zooplankton from shallow coastal environments (Ohlhorst 1982, Youngbluth 1982, Jacoby and Greenwood 1988, 1989, Saint-Jean and Pagano 1990, Buskey 1993). In Puerto Rico, there is evidence of higher abundance of most taxa, including copepods, during night-time collections in several coastal locations around the island (Youngbluth 1979, 1980).

Most of the field studies on species of Pseudodiaptomus in tropical and subtropical environments consist of descriptions of their vertical movements or substratum preference (Hart and Allanson 1976, Hart 1978, Hutchins 1985, Jacoby and Greenwood 1988, 1989,
Saint-Jean and Pagano 1990). Other research focuses on the diel feeding rhythmicity (Hart 1977). Experimental research using cultures of the three species of Pseudodiaptomus found in the Caribbean, P. acutus, P. cokeri and $P$. marshi, have provided important information on their life history and mating behavior (Jacoby and Youngbluth 1983). No ecological work has been conducted on natural populations of $P$. cokeri. This paper investigates the relationship between environmental factors and the temporal and spatial patterns of abundance of Pseudodiaptomus cokeri in Phosphorescent Bay, Puerto Rico, throughout an annual cycle. Special emphasis was devoted to describe the variations in abundance of the copepodite and adult stages (e.g. male, female and ovigerous female) of Pseudodiaptomus cokeri.

\section{MATERIALS AND METHODS}

The southern coastline of Puerto Rico is sculptured with small bays, which may be broadly open or nearly enclosed, and is generally bordered by dense growths of mangroves. One of these bays is Phosphorescent Bay, which is located towards the southwest end of the island $\left(17^{\circ} 58^{\prime} 30^{\prime \prime} \mathrm{N} ; 67^{\circ} 01^{\prime} 10^{\prime \prime} \mathrm{W}\right)$. The bay is a protected estuarine environment with a surface area of $c a .19$ hectares and a mean depth of $2.5 \mathrm{~m}$ (Coker and González 1960). It connects with offshore waters through a narrow opening about $158 \mathrm{~m}$ wide. A sandy substratum covers most of the shallow borders of the bay together with small patches of turtle grass, Thalassia testudinum, and a variety of macroalgal species. Turtle grass, sometimes mixed with manatee grass, Syringodium filiforme, grows also on sections of the south border of the bay. The central area of the bay has fine muddy sediment. This area constitutes the deepest and most extensive portion of the bay, with depths ranging down to $4.5 \mathrm{~m}$. Organic detritus mainly originating from the surrounding red mangroves constitute the majority of this loose muddy substratum. Most of the central portion of the embayment has reduced light 
penetration with the deeper areas considerably darker. Secchi disk readings vary from 0.9 to $3.4 \mathrm{~m}$ (mean = $2.0 \mathrm{~m})$ (González 1967). There is no macroalgal or seagrass growth in this area. High turbidity in Phosphorescent Bay has been associated with high phytoplankton concentrations, debris from the mangrove swamp, rainfall runoff and stirring of loose sediments by wind and fishes (Burkholder and Burkholder 1958).

Routine sampling of zooplankton abundance was performed biweekly during one year (May, 1992 - April, 1993) at three stations in Phosphorescent Bay. Representative substrate environments were selected as sampling stations based on observations of the biological, morphological and sedimentological characteristics of the bottom. Sampling stations were: $\mathrm{S}$ 1 , center of the bay (depth $=4-5 \mathrm{~m}$ ); S-2, north coast of the bay, near the middle mangrove channel (depth $=2-4 \mathrm{~m}$ ); and S-3, south coast (depth $=1-3 \mathrm{~m})$. Station $\mathrm{S}-1$ was aproximately equidistant $(100 \mathrm{~m})$ to stations $\mathrm{S}-2$ and $\mathrm{S}-3$.

Nocturnal oblique tows (21:00-23:00 hr) were performed with a conical net (mouth diameter $=0.5 \mathrm{~m}$; mesh size $=135 \mu \mathrm{m})$ and a standard calibrated flowmeter (General Oceanics). At least three replicate tows were taken at each station. Zooplankton samples were fixed in $4 \%$ formalin solution, and then preserved in $70 \%$ ethanol. Water temperature and salinity measurements were taken at the surface and near the bottom at each station before towing activities using a SCT meter to obtain a water column mean value for each sample/station set. Water samples for determining chlorophyll-a concentration were obtained using a Van Dorn bottle. Chlorophyll-a concentrations were fluorometrically determined (Phinney and Yentsch 1985). Monthly precipitation values were obtained from the meteorological station at Isla Magueyes, approximately $3.4 \mathrm{~km}$ west of Phosphorescent Bay.

The mean abundance of Pseudodiaptomus cokeri was estimated from 2-3 subsamples (volume $=5-20 \mathrm{ml}$ ) drawn with a Stempel pipette. The abundance of $P$. cokeri was reported separately for adult males, adult females, ovigerous females and copepodites. Total zooplankton abundance was also estimated for each sample. The temporal and spatial patterns of abundance of $P$. cokeri were analyzed using analysis of variance (ANOVA) with replication statistics. A two-way ANOVA was applied first to the biweekly abundance data to test for differences between dates (temporal patterns), sampling stations (spatial patterns), and interaction effects. A one-way ANOVA was used to test differences in abundance between stations on each date, and between dates at each station. Significant differences were further analyzed using Tukey's test to identify differences of abundance means between dates at each station and between stations on each date. Preliminary inspection of the data revealed that sample variances were not homogeneous (Hartley's $\mathrm{F}_{\text {max }}$ Test) and abundance values asymetrical (Lilliefors Test). Therefore, a $\log _{10}(x+1)$ transformation was employed to equalize variances and normalize distributions before using ANOVA procedures. Variances were homogeneous for all $P$. cokeri categories after transformation, and their abundance data did not significantly deviate from normality. Correlation coefficients were calculated to relate abundance to physical, chemical and biological parameters, including chlorophyll-a concentrations.

\section{RESULTS}

The water temperature in Phosphorescent Bay ranged from $24.9{ }^{\circ} \mathrm{C}$ in December to $30.3^{\circ} \mathrm{C}$ in July, $1992\left(\right.$ mean $\left.=27.9^{\circ} \mathrm{C}\right)$; cumulative monthly precipitation was lowest in March, 1992 with $0.3 \mathrm{~cm}$ and highest in May, 1993 with $26.1 \mathrm{~cm}($ mean $=8.5 \mathrm{~cm})$. A seasonal pattern of higher temperature and rainfall prevailed from April to November; whereas lower water temperature and rainfall were registered from May to October (Fig. 1). Based on such seasonal trends, the April - November period was denominated the warm/wet season, and the December - March period the cool/dry season. Salinity fluctuated from a maximum of $38.0 \mathrm{~S}^{0 / 00}$ in July to a minimum of $29.9 \mathrm{~S}^{0 / 00}$ in 
December. Peak values were associated with extended periods of two or more months of low rainfall in July and January. Low salinity values were registered during and after high precipitation events in November and December (Fig. 1). There was a slight difference in water temperature and salinity between sampling stations (Coefficient of Variation of temperature $=$ $1.27 \%$; C.V. salinity $=0.78 \%$ ). No stratification was observed in the water column during the period of study. The greatest difference
0.01 ). Biweekly variations in chlorophyll-a concentrations throughout the year-cycle showed a progressive increase during and after the rainy season, with peaks in September, October and December. One-way ANOVA test revealed differences between the three sampling stations (Fig. 2). In most cases, concentrations were significantly higher in S-2 with respect to $S-1$ and $S-3$ (Tukey's test; $p<0.05$ ).

Salinity was significantly correlated $(p<0.05)$ with temperature $(r=0.490)$, but

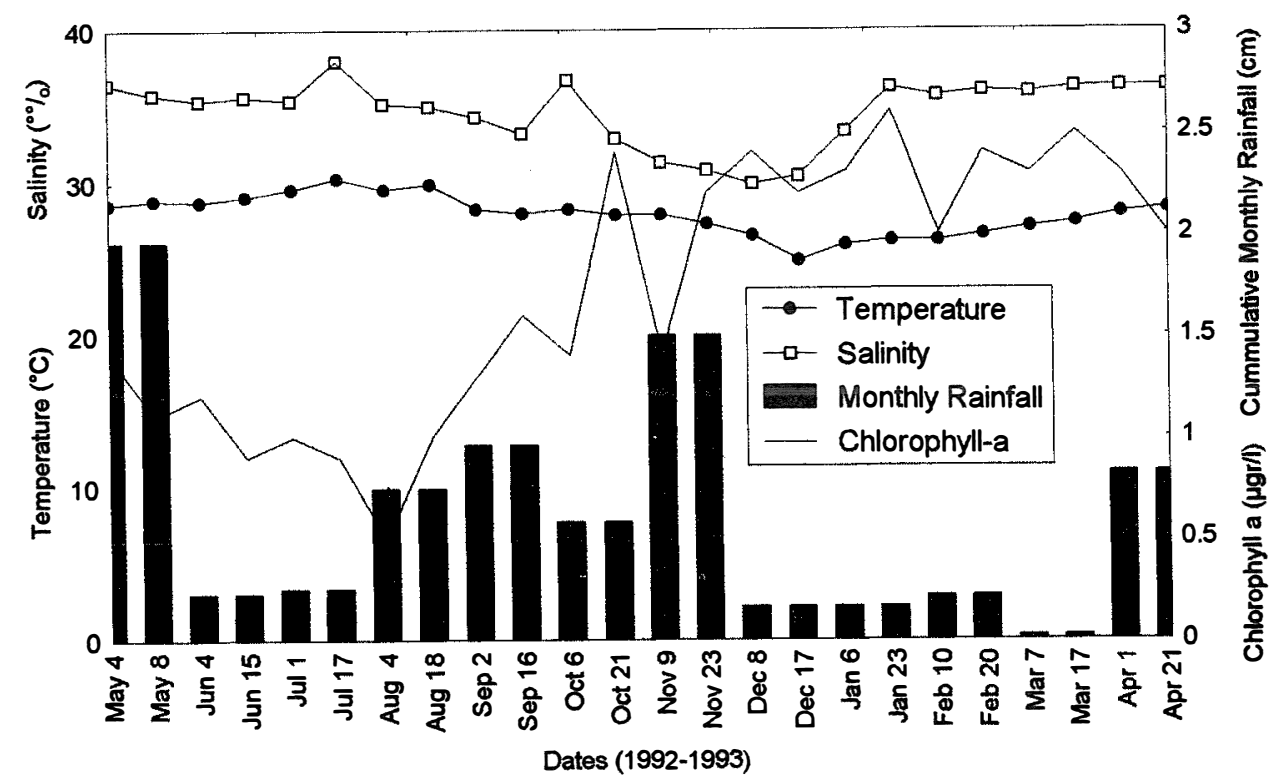

Fig. 1. Variations in temperature, salinity, chlorophyll-a and rainfall in Phosphorescent Bay. Values are means for the three sampling stations inside the bay.

between surface and near-bottom readings of temperature was of $1{ }^{\circ} \mathrm{C}$.

Biweekly (station) means of chlorophyll-a concentrations ranged between 0.47 and 2.57 $\mu \mathrm{g} / \mathrm{l}$ (mean \pm 1 standard deviation $=1.7 \pm 0.68$ $\mu \mathrm{g} / \mathrm{l})$ (Fig. 1). This range in chlorophyll-a concentrations is within previously reported concentrations for Phosphorescent Bay and adyacent waters (Margalef, 1961). Chlorophyll-a concentrations were higher from December to March (range $=2.0-2.6 \mu \mathrm{g} / \mathrm{l}$ ) relative to the May - November period (including April, 1993) (range 0.5 - $2.3 \mu \mathrm{g} / \mathrm{l}$ )(Student-T test, $\mathrm{p}<$ showed no significant correlation with rainfall $(r=-0.061)$. In spite of the coincidence in variations of temperature and cumulative rainfall throughout the year (Fig. 1), no significant correlation $(r=0.351)$ was found between them. A significant $(\mathrm{p}<0.01)$ negative correlation $(\mathrm{r}=$ 0.752 ) resulted between the biweekly concentrations of chlorophyll-a and water temperature. Correlation coefficients indicate no clear linear relationship between salinity, chlorophyll-a concentrations $(r=-0.222)$ and abundance of Pseudodiaptomus cokeri $(\mathrm{r}=-0.168)$ in Phosphorescent Bay. The low correlation 


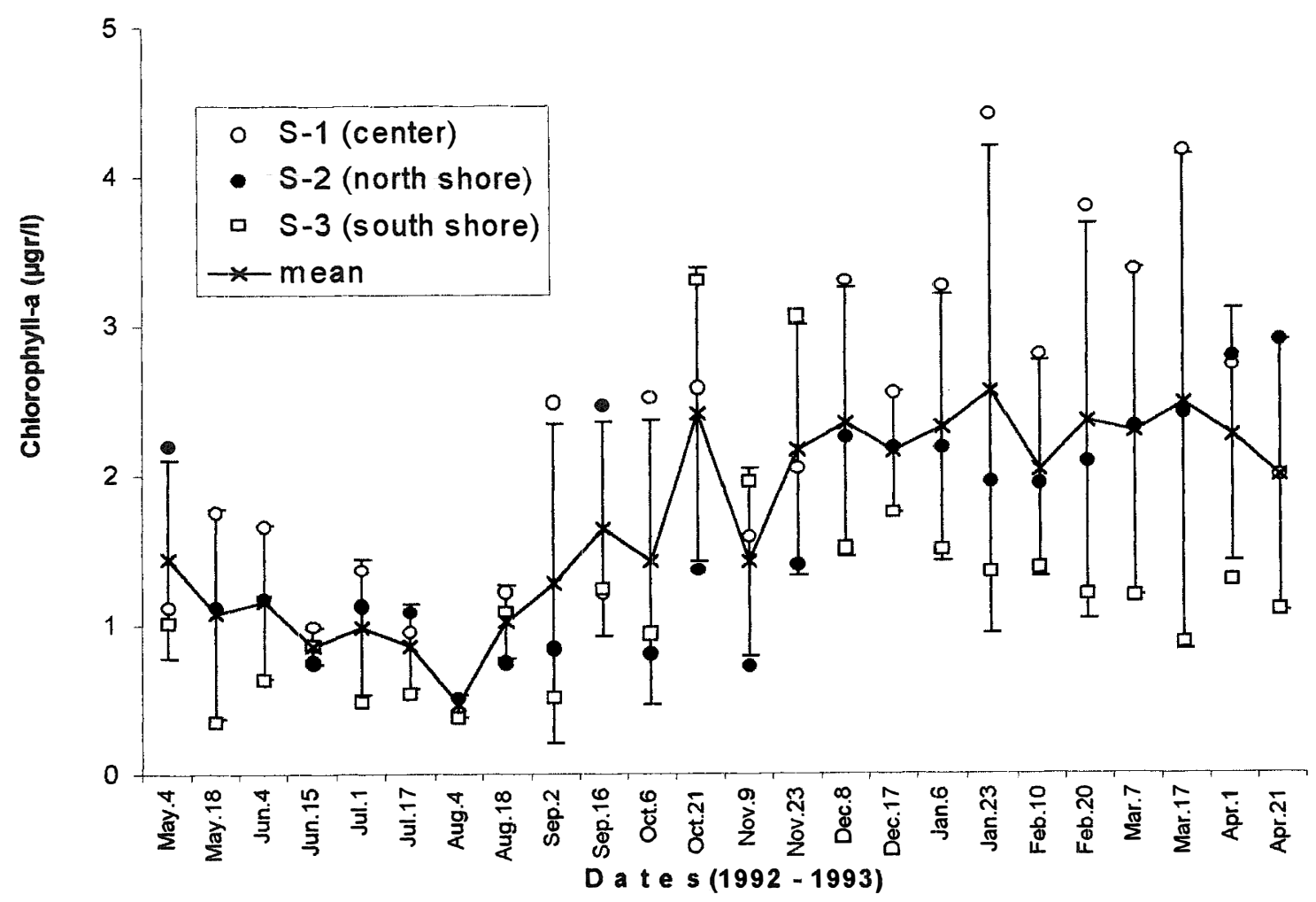

Fig. 2. Biweekly variations in concentrations of chlorophyll-a measured at sampling stations S-1 (center), S-2 (north shore) and S-3 (south shore) (means with \pm 1 standard deviation).

coefficient $(r=-0.209)$ between cumulative rainfall and chlorophyll-a concentration, indicate no relationship between these variables. Significant negative correlations of Pseudodiaptomus cokeri to water temperature $(r=-0.847 ; \mathrm{p}<0.01)$ and rainfall $(r=-0.446 ; p<0.05)$; and a positive correlation to chlorophyll-a concentration $(r=0.654$; $\mathrm{p}<0.01$ ) were observed.

The males, females, ovigerous females and copepodites of Pseudodiaptomus cokeri were present throughout the year at the three sampling stations, although numbers for all $P$. cokeri categories were significantly higher during the cool/dry season (ANOVA, $\mathrm{p}<0.05$ ) (Table 1 , Fig. 3). Maximum total abundance (6 404 ind. $\mathrm{m}^{-3}$ ) and minimum total abundance (146 ind. $\mathrm{m}^{-3}$ ) were recorded in December and September, 1992, respectively (mean $=7005$ ind. $\mathrm{m}^{-3}$ ). A similar trend of variation in abundance was detected for adults and copepodite instars, with a lower number of individuals and smaller fluctuations from May to November, 1992 (warm/wet season). The abundance increased and peaked in December, 1992, maintaining numbers an order of magnitude higher until March, 1993 (cool/dry season). 
TABLE 1

Seasonal abundance of Pseudodiaptomus cokeri in Phosphorescent Bay. Values are mean abundance of sampling stations $S-1, S-2$ and $S-3( \pm 1$ standard deviation).

\begin{tabular}{|c|c|c|c|c|c|c|}
\hline & $\begin{array}{l}\text { Warm / Wet season } \\
\text { (April - November) }\end{array}$ & & $\begin{array}{l}\text { Cool / Dry season } \\
\text { (December-March) }\end{array}$ & \multicolumn{3}{|c|}{$\begin{array}{c}\text { Study period } \\
\text { (May, 1992 - April, 1993) }\end{array}$} \\
\hline $\begin{array}{l}\text { Temperature } \\
\text { Precipitation }\end{array}$ & $\begin{array}{l}27.3-30.3^{\circ} \mathrm{C} \\
3.1-26.1 \mathrm{~cm}\end{array}$ & & $\begin{array}{c}24.9-27.4^{\circ} \mathrm{C} \\
0.3-2.9 \mathrm{~cm}\end{array}$ & & $\begin{array}{c}24.9-30.3^{\circ} \mathrm{C} \\
0.3-26.1 \mathrm{~cm}\end{array}$ & \\
\hline & $\begin{array}{l}\text { Mean abundance } \\
\quad \text { (Inds. } \mathrm{m}^{-3} \text { ) }\end{array}$ & $\begin{array}{c}\% \\
\text { Total }\end{array}$ & $\begin{array}{l}\text { Mean abundance } \\
\text { (Inds. } \mathrm{m}^{-3} \text { ) }\end{array}$ & $\begin{array}{c}\% \\
\text { Total }\end{array}$ & $\begin{array}{l}\text { Mean abundance } \\
\text { (Inds. } \mathrm{m}^{-3} \text { ) }\end{array}$ & $\begin{array}{c}\% \\
\text { Total }\end{array}$ \\
\hline $\begin{array}{l}\text { Pseudodiaptomus cokeri } \\
\text { Males } \\
\text { Females } \\
\text { Ovigerous females } \\
\text { Copepodites } \\
\text { Total }\end{array}$ & $\begin{array}{c}133 \pm 44 \\
29 \pm 8 \\
64 \pm 34 \\
484 \pm 198 \\
710 \pm 282\end{array}$ & $\begin{array}{l}18.7 \\
4.1 \\
9.0 \\
68.2 \\
100\end{array}$ & $\begin{array}{c}699 \pm 341 \\
85 \pm 25 \\
205 \pm 88 \\
3204 \pm 2121 \\
4191 \pm 1444\end{array}$ & $\begin{array}{c}16.7 \\
2.0 \\
4.9 \\
76.4 \\
100\end{array}$ & $\begin{array}{c}322 \pm 218 \\
48 \pm 32 \\
111 \pm 80 \\
1391 \pm 836 \\
1870 \pm 1099\end{array}$ & $\begin{array}{c}17.2 \\
2.6 \\
5.9 \\
74.4 \\
100\end{array}$ \\
\hline
\end{tabular}

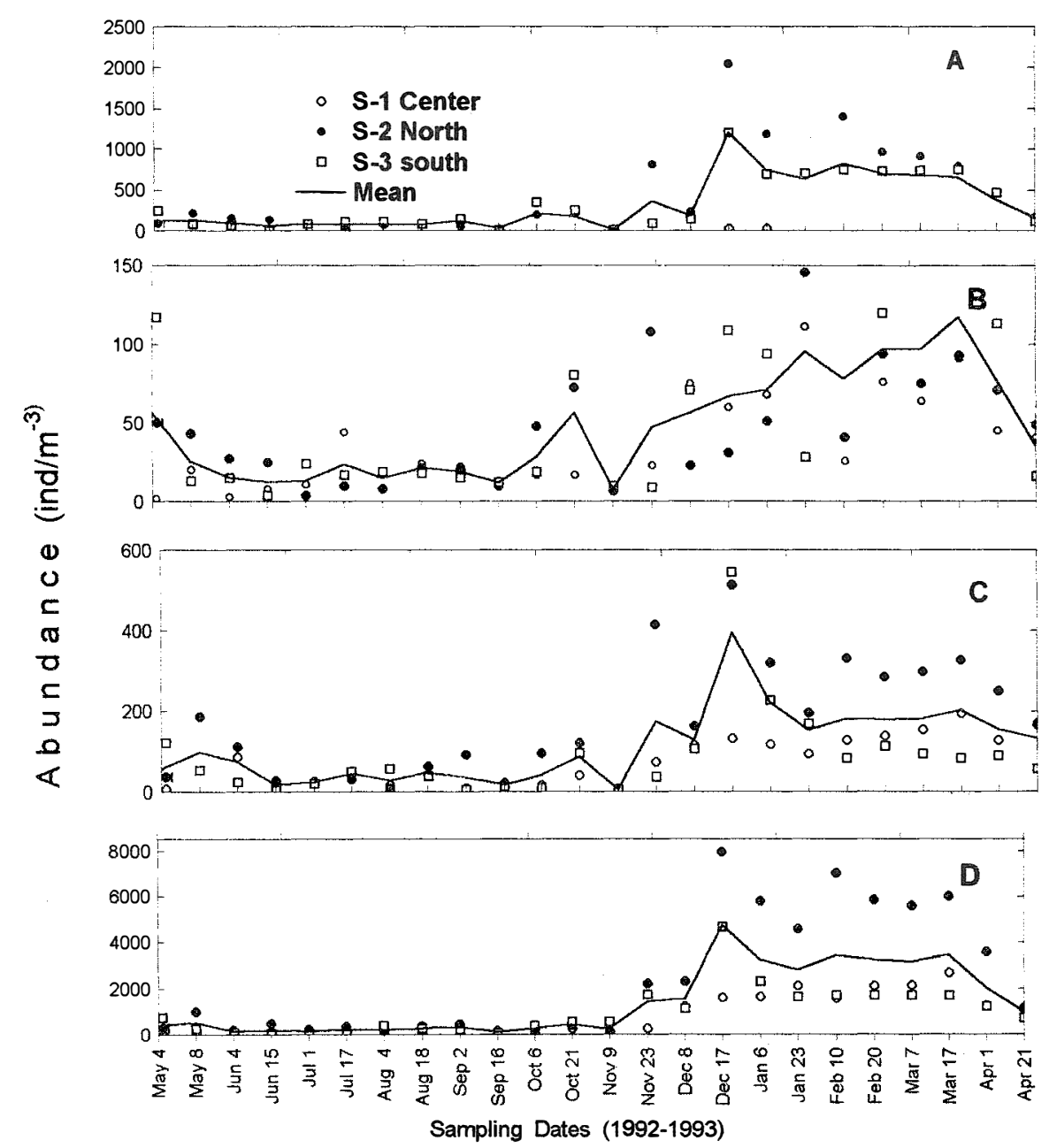

Fig. 3. Temporal and spatial distribution of Pseudodiaptomus cokeri in Phosphorescent Bay. A) Adult males, B) Adult females, C) Ovigerous females, and D) Copepodites. 
A posteriori multiple mean comparisons tests (Tukey's test) from the ANOVA procedures indicated that total abundance of $P$. cokeri were always higher at station S-2 during the cool/dry season from December to March (Table 2). The rest of the year, no clear pattern of spatial distribution of $P$. cokeri was defined, and higher abundances occurred in times at any of the three stations $\mathrm{S}-1, \mathrm{~S}-2$ or $\mathrm{S}-3$. In other three occasions, no significant difference between sampling stations was observed.

\section{DISCUSSION}

The seasonal variations in abundance of Pseudodiaptomus cokeri in Phosphorescent Bay appear to be regulated by interactions of climatic and biological factors. The pattern of $P$. cokeri abundance coincided with variations in chlorophyll-a concentrations, with higher number of individuals occurring during the $\mathrm{cool} /$ dry season, when chlorophyll-a values were also highest. This fact suggest that copepod abundance was, at least in part, regulated

TABLE 2

One-way analyses of variance (ANOVA) testing the effect of sampling stations on biweekly abundance of Pseudodiaptomus cokeri in Phosphorescent Bay.

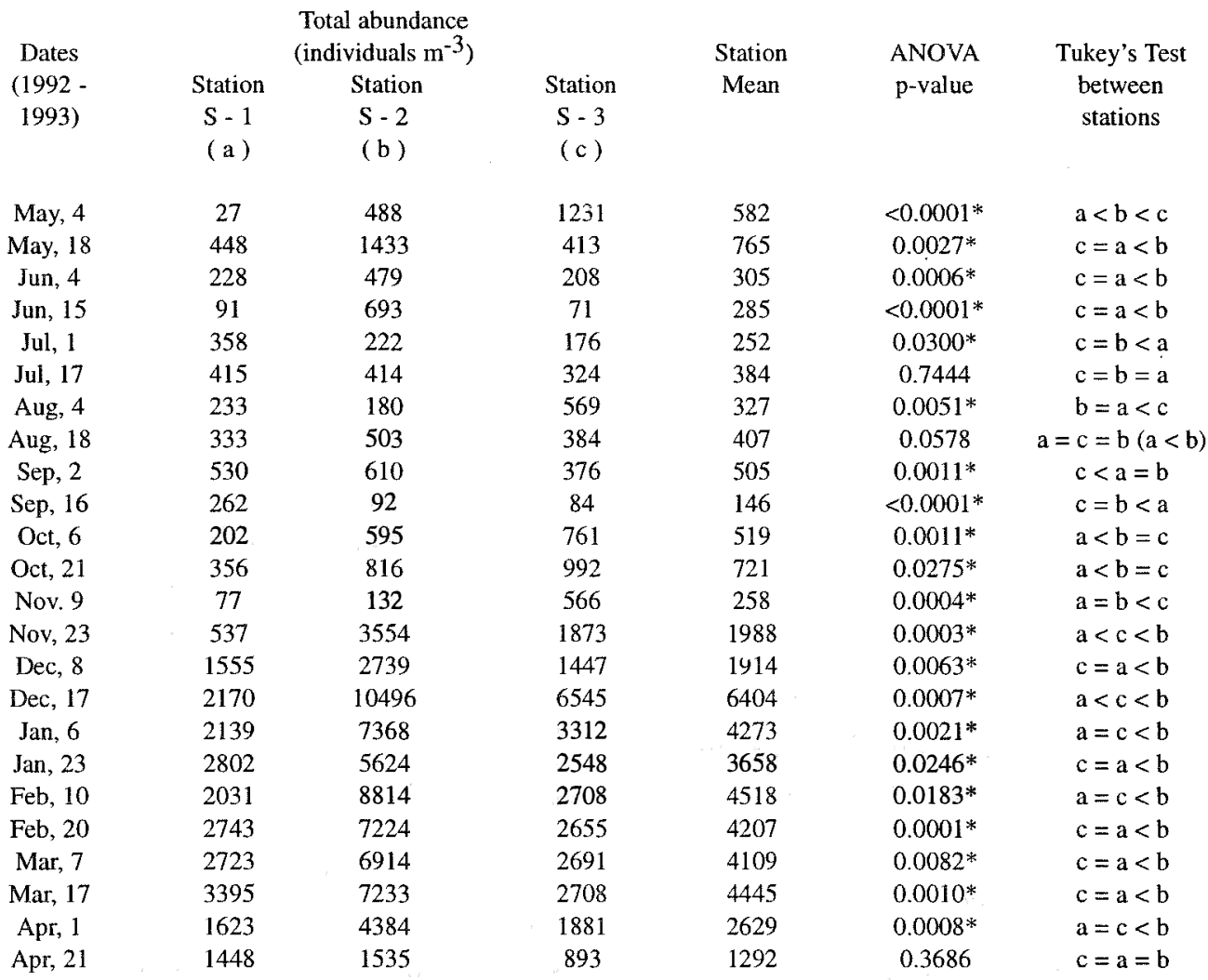

Multiple comparisons of station means using Tukey's Test * $=p<0.05$. 
by food availability (e.g. phytoplankton). Phytoplankton increased after periods of higher cummulative monthly precipitation in the bay. Exogenous nutrient inputs from rainfall runoffmay have a fertilizing effect on phytoplankton either immediately or after a time lag (Purcell 1980, García and López 1989, Jordan et al. 1991). Nutrient enrichment associated with the seasonal rainfall patterns is a key factor regulating temporal variations in standing stocks of phytoplankton and zooplankton (mostly copepods) in coastal environments of Puerto Rico (García and López 1989) and the U.S. Virgin Islands (Purcell 1980). Nutrient remineralization after the rainy season was also considered an important factor of plankton abundance in Biscayne Bay, Florida (Woodmansee 1958, Reeve 1964) and in Laurel Reef, La Parguera, Puerto Rico (Glynn 1973). During the short period of lower rainfall between December and March, nutrient inputs from the watershed probably declined in Phosphorescent Bay. Phytoplankton standing stocks, however, probably remained high during this period due to autochthonous remineralization processes.

The abundance decline of Pseudodiaptomus cokeri during the warm/wet season may be explained by a decrease of phytoplankton standing stocks, as indicated by chlorophyll-a concentrations. Salinity appears to play a minor role in influencing temporal distribution patterns of this species in Phosphorescent Bay. No significant relationship was found between salinity and total $P$. cokeri abundance. The negative association between temperature and total $P$. cokeri abundance reflects the inverse relationship existing between temperature and phytoplankton (chlorophyll-a concentration).

Results of this investigation support the hypothesis that food limitation (e.g. phytoplankton standing stocks) regulate the abundance of Pseudodiaptomus cokeri in Phosphorescent Bay. The concept of food limitation has been supported by laboratory experiments and field observations which have shown that growth and reproduction in copepods (e.g. Acartia tonsa) can be limited by food concentration (Checkley 1980, Durbin et al. 1983,
Ambler 1985, Paffenhöfer and Stearns 1988). Thus, since mean chlorophyll-a concentration recorded in Phosphorescent Bay was significantly lower during the warm/wet season relative to the cool/dry season (Student-T test, $\mathrm{p}<$ 0.01 ), low food availability could be expected to have had a limiting effect on herbivorous zooplankton. Probably the fast turnover of phytoplankton was a key factor that permitted the high numbers of $P$. cokeri in Phosphorescent Bay.

Similar variations in abundance of copepod populations have been reported in other nearshore localities of Puerto Rico (Youngbluth 1979, García and López 1989) and complement those described for the total zooplankton abundance in Phosphorescent Bay (Rios-Jara, in prep.). Fluctuations in these localities were closely related to the annual rainfall pattern with associated nutrient inputs from land drainage and consequent increases in phytoplankton productivity. In other embayments of Puerto Rico, P. cokeri is occasionally very abundant (Youngbluth 1979, 1980). Ovigerous females and copepodites of $P$. cokeri were always present in the bay, indicating a continuous reproductive activity. Other species of Pseudodiaptomus (e.g. P. marinus) are listed among the copepods recommended for mass cultivation (Iwasaki and Kamiya 1977). The data from this investigation may be useful in estimating the potential production of $P$. cokeri in Phosphorescent Bay as a food source for fish larvae. This information may also be useful for determinations of secondary production in tropical estuarine environments.

The seasonal changes of zooplankton abundance may be influenced by the abundance of predators as well. Predator-prey interactions have been proved to be important in structuring the zooplankton community (e.g. Fulton 1985, Fancett and Jenkins 1988, Bamstedt 1990), and a major factor determining the distribution of copepods (Rippingale and Hodgkin 1974, Iwasa 1982, Fancett and Kimmerer 1985, García and Durbin 1993). Pseudodiaptomus hessei forms a major part in the diet of estuarine fish and mysids (Wooldridge and Bailey 1982). Escape 
response through vertical migration and a benthic daytime existence may reduce relative predation in demersal copepod populations (Jerling and Wooldridge 1991). Gelatinous zooplankton were sometimes present but inadequately sampled in Phosphorescent Bay. Some ctenophore blooms were detected after heavy rain events in September and October. However, the lack of population estimates of abundance of these and other possible predators prevent any further considerations in this study.

Differences in abundance of $P$. cokeri between sampling stations could be related to the different types of substratum found in Phosphorescent Bay. Both adult and copepodite stages of $P$. cokeri were more abundant at stations S-2 and/or S-3 (north and south shores, respectively), relative to $S-1$ (center of the bay) on 19 out of 24 sampling dates. Daytime collections showed that $P$. cokeri was most frequent over the vegetated bottoms found in the shallower coastline around the bay than in the unvegetated mud substratum of the central part of the bay. Apparently, this species prefers areas with heterogeneous substrata. Jacobs (1961) observed that $P$. coronatus sinks rapidly when not swimming and can cling tightly to substrata; $P$. cokeri has a similar behavior (Jacoby and Youngbluth 1983). This has been interpreted as an active mechanism that prevents individuals from being washed out of the system (Castel and Veiga 1990).

Pseudodiaptomus cokeri can be classified as endemic, in the sense that it inhabits only enclosed bays, its demersal behavior may contribute to its restricted distribution inside the bay (González and Bowman 1965). Transport studies in planktic animals have demonstrated that individuals remaining in surface waters are passively transported outside coastal systems by tidal currents to adjacent neritic waters (Fontier and Leggett 1982); whereas those remaining in near-bottom waters accumulate inside (Laprise and Dodson 1990, 1993). Consequently, vertical migration may be an important mechanism allowing retention of drifting animals inside coastal semi-enclosed ecosystems. Copepodite and adult stages showed strong vertical migration and probably maintained their vertical position in the water column of the bay by means of vertical movements through the water column (Rios-Jara, in prep.). This has been demonstrated for several coastal species (Trinast 1975, Jacobs 1968, Wooldridge and Erasmus 1980, Alcaraz 1983). Restriction to nearshore environments has been explained as a strategy to remain in high-food environments (Paffenhöfer and Stearns 1988). Pseudodiaptomus is a typical estuarine-coastal genus, found only in shallow inshore waters, where the food supply is generally abundant (González and Bowman 1965).

There are temporally stable areas of high or low densities of $P$. cokeri in Phosphorescent Bay, causal mechanism(s) of these temporal changes in abundance affect differently in the various areas of the bay throughout the year. The effect of these factors are less apparent during the warm/wet season. Thus, it is suggested that $P$. cokeri displays a small scale patchiness. This pattern is comparable to observations on the spatial distribution of zooplankton abundance from other coastal (Youngbluth 1980, García and Durbin 1993) and oceanic (Yoshioka et al. 1985) environments of Puerto Rico. Most importantly, these results suggest that abiotic and biotic relationships directly influence abundance of plankton in Caribbean coastal environments and that zooplankton assemblages are not simply the result of species independently sorting in diverse environments according to physiological tolerances. A deeper understanding of the relative importance of the factors resposible for the variability observed in abundance requires further studies on the appropiate temporal and spatial scales, since the distribution of demersal copepods is heavily dependent on the coupling between the physical and biological processes.

\section{ACKNOWLEDGMENTS}

This study is part of a research on the zooplankton community of Phosphorescent Bay which was submitted in partial fulfillment of the 
requirements for the Doctor of Philosophy degree in Marine Sciences from the Department of Marine Sciences, University of Puerto Rico in Mayagüez (DMS-UPR). I thank the members of my dissertation committee, Juan G. González Lagoa, Jorge R. García Sais, Allen R. Lewis, Stuart Ramos Biaggi and James S. Beaver, for invaluable help throughout the course of this research. This study was partially supported by the Universidad de Guadalajara, México and the DMS-UPR.

\section{RESUMEN}

Este estudio analiza las variaciones estacionales en abundancia del copépodo demersal Pseudodiaptomus cokeri en tres localidades de muestreo (centro y orillas norte y sur) de Bahía Fosforescente, Puerto Rico, durante un ciclo anual. Se realizaron arrastres oblicuos por triplicado durante la noche (21:00-23:00 hr) en las tres localidades cada quince dias con una red cónica (diámetro $=0.5 \mathrm{~m}$; luz de malla $=135 \mu \mathrm{m}$ ) y un flujómetro standard calibrado. $\mathrm{La}$ temperatura del agua y su salinidad se registraron en la superficie y cerca del fondo en cada localidad antes de los arrastres usando un sensor SCT. La concentración de clorofila-a se determinó mediante fluorometría. Los estadios adulto y copepodito de esta especie representaron aproximadamente el $1.6 \%$ de la abundancia promedio anual del zooplancton total de la bahía. La mayor abundancia de $P$. cokeri (media $\pm 1 \mathrm{SD}=4191 \pm 1444$ individuos $\mathrm{m}^{-3}$ ) estuvo asociada con temperaturas relativamente bajas y condiciones secas (estación fría /seca), las cuales prevalecieron entre diciembre y marzo en relación al periodo entre abril y noviembre (estación cálido/húmeda), con menor abundancia. Las fluctuaciones de esta población coincidieron con los incrementos progresivos en las concentraciones de clorofila-a en las tres localidades (ANOVA de una vía, $\mathrm{p}<0.05$ ). Sin embargo, la abundancia fue generalmente mayor en la orilla norte de la bahía (Prueba de Tukey, $\mathrm{p}<0.05$ ). Las diferencias en abundancia de $P$. cokeri entre las localidades de muestreo pueden relacionarse con los diferentes tipos de sustrato encontrados en la bahía. Aparentemente, esta especie prefiere areas con sustrato heterogéneo. Su comportamiento demersal podría explicar la distribución observada dentro de la bahía.

\section{REFERENCES}

Alcaraz, M. 1983. Coexistence and segregation of congeneric pelagic copepods: spatial distribution of the A sartia complex in the ria of Vigo (N.W. Spain). J. Plankton Res. 5: 891-900.
Ambler, J.W. 1985. Seasonal factors affecting egg production and variability of eggs of Acartia tonsa Dana from East Lagoon, Galveston, Texas. Estuar. Coast. Shelf Sci. 20: 743-760.

Bacon, P.R. 1971. Plankton studies in a Caribbean estuarine environment. Carib. J. Sci. 11: 81-89.

Bamstedt, U. 1990. Throphodynamics of the scyphomedusae Aurelia aurita. Predation rate in relation to abundance, size and type of prey organism. J. Plank. Res. 12: $215-230$.

Bowman, T.E. 1978. From Brazil to Jamaica: a range extension of the neritic calanoid copepod, Pseudodiaptomus acutus. Crustaceana 35: 249-252.

Burkholder, P.R. \& L.M. Burkholder. 1958. Studies on B vitamins in relation to productivity of the Bahia Fosforescente, Puerto Rico. Bull. Mar. Sci. Gulf. Carib. 8: 201-233.

Buskey, E.J. 1993. Annual pattern of micro- and mesozooplankton abundance and biomass in a subtropical estuary. J. Plankton Res. 15: 907-924.

Campos, A. \& E. Suárez-Morales. 1994. Copépodos pelágicos del Golfo de México y Mar Caribe I. Biología y Sistemática. CONACyT/CIQRO. Chetumal, México. $359 \mathrm{pp}$.

Castel, J. \& J. Veiga. 1990. Distribution and retention of the copepod Eurytemora affinis hirundoides in a turbid estuary. Mar. Biol. 107: 119-128.

Checkley, D.M. 1980. The egg production of a marine planktonic copepod in relation to its food supply: laboratory studies. Limnol. Oceanogr. 25: 430-446.

Coker, R.E. \& J.G. González. 1960. Limnetic copepod populations of Bahía Fosforescente and adjacent waters. Puerto Rico J. Elisha Mitchell Sci. Soc. 76: 8-28.

Durbin, E.G., A.G. Durbin, T.J. Smayda \& P.G. Verity. 1983. Food limitation and production by adult Acartia tonsa in Narragansett Bay, Rhode Island. Limnol. Oceanogr. 28: 1199-1213.

Fancett, M.S. \& W.J. Kimmerer. 1985. Vertical migration of the demersal copepod Pseudodiaptomus as a means of predator avoidance. J. Exp. Mar. Biol. Ecol. 88: 31-43.

Fancett, M.S. \& G.P Jenkins. 1988. Predatory impact of scyphomedusae on ichthyoplankton and other zooplankton in Port Phillip Bay. J. Exp. Mar. Biol. Ecol. 116: 63-77. 
Fontier, L. \& W.C. Leggett. 1982. Fickian transport and the dispersal of fish larvae in estuaries. Can. J. Fish. Aquat. Sci. 39: 1150-1163.

Fulton, R.S. III. 1985. Predator-prey relationships in an estuarine littoral copepod community. Ecology 66: 21-29.

García, J.R. \& E. Durbin. 1993. Zooplanktivorous pr dation by large scyphomedusae Phyllorhiza punctata (Cnidaria: Scyphozoa) in Laguna Joyuda. J. Exp. Mar. Biol. Ecol. 173: 71-93.

García, J.R. \& J.M. López. 1989. Seasonal patterns of phytoplankton productivity, zooplankton abundance and hydrological conditions in Laguna Joyuda, Puerto Rico, p. 625-631. In J.D. Ros (ed.). Topics in Marine Biology. Scientia Marina 53.

Glynn, P.W. 1973. Ecology of Caribbean coral reef. The Porites reef-flat biotope: Part II plankton community with evidence of depletion. Mar. Biol. 22: 1-22.

González, J.G. 1967. Primary productivity of the neritic and offshore waters of western Puerto Rico. U.S. Office of Naval Research, Washington, D.C. 11 p.

González, J.G. 1980. Responses of coastal and estuarine animals to high temperatures: a possible impact from heated industrial effluents. Water Resources Research Institute, Mayagüez, Puerto Rico. 46 p.

González, J.G. \& T.E. Bowman. 1965. Planktonic copepods from Bahía Fosforescente, Puerto Rico and adjacent waters. U.S. Nat. Mus. Proc. 117: 241-303.

Hart, R.C. 1977. Feeding rhythmicity in a migratory copepod (Pseudodiaptomus hessei [Mrázek]). Freshwater Biol. 7: 1-8.

Hart, R.C. 1978. Horizontal distribution of the copepod Pseudodiaptomus hessei in subtropical Lake Sibaya. Freshwater Biol. 8: 415-421.

Hart, R.C. \& B.R. Allanson. 1976. The distribution and diel vertical migration of Pseudodiaptomus hessei (Mrázek) (Calanoidea:Copepoda) in a subtropical lake in Southern Africa. Freshwater Biol. 6: 183-198.

Hutchins, L. 1985. Vertical distribution of mesozooplankton at an active upwelling site in the Southern Benguela Current, December 1969. South Africa Sea Fisheries Research, Cape Town, South Africa. 67 p.

Iwasa, Y. 1982. Vertical migration of zooplankton: a game between predator and prey. Am. Nat. 120: 71-179.
Iwasaki, H. \& S. Kamiya. 1977. Cultivation of the marine copepod, Pseudodiaptomus marinus Sato. Inf. Bull. Planktol. Jap. 24: 44-54.

Jacobs, J. 1961. Laboratory cultivation of the marine copepod Pseudodiaptomus coronatus. Limnol. Oceanogr. 6: $43-446$.

Jacobs, J. 1968 Animal behavior and water movements as co-determinants of zooplankton distribution in a tidal system. Sarsia 34: 355-370.

Jacoby, C.A. \& M.J. Youngbluth. 1983. Mating behavior in three species of Pseudodiaptomus (Copepoda: Calanoidea). Mar. Biol. 76: 77-86.

Jacoby, C.A. \& J.G. Greenwood. 1988. Spatial, temporal and behavioral patterns in emergence of zooplankton in the lagoon of Heron Reef, Great Barrier Reef of Australia. Mar. Biol. 97: 309-328.

Jacoby, C.A. \& J.G. Greenwood. 1989. Emergent zooplankton in Moreton Bay, Queensland, Australia: seasonal, lunar and diel patterns in emergence and distribution with respect to substrata. Mar. Biol. 51: 131-154.

Jerling, H.L. \& T.H. Wooldridge. 1991. Population dynamics and estimates of production for the calanoid copepod Pseudodiaptomus hessei in a warm temperate estuary. Estuar. Coast. Res. Sci. 33: 121-135

Jordan, T.E., D.R. Correll, J. Miklas \& D.E. Weller. 1991. Long-term trends in estuarine nutrients and chlorophyll, and short-term effects on variations in watershed discharge. Mar. Ecol. Prog. Ser. 75: 121-132.

Laprise, R. \& J.J. Dodson. 1990. The mechanism of retention of pelagic tomcod, Microgadus tomcod, larvae and juveniles in the well mixed part of the St. Lawrence Estuary. Environ. Biol. Fish. 29: 293-302.

Laprise, R. \& J.J. Dodson. 1993. Nature of the environmental variability experienced by benthic and pelagic animals in the St. Lawrence Estuary, Canada. Mar. Ecol. Prog. Ser. 94: 129-139.

Margalef, R. 1961. Hidrografía y fitoplancton de un área marina de la costa meridional de Puerto Rico. Inv. Pesq. 18: 33.96.

Ohlhorst, S.L. 1982. Diel migration patterns of demersal reef zooplankton. J. Exp. Mar. Biol. Ecol. 60: 1-15.

Olivieri Vega, R.A. 1987. Effects of thermal effluent of a power plant on the survival rate and population densities of the copepods Acartia tonsa Dana and A. lillgeborgii Giesbrecht in a cove of Guayanilla Bay, Puerto 
Rico. M.Sc. Thesis, University of Puerto Rico, Mayagüez, Puerto Rico.

Paffenhöfer, G.A. \& D.E. Stearns. 1988. Why is Acartia tonsa (Copepoda:Calanoida) restricted to nearshore environments? Mar. Ecol. Prog. Ser. 42: 33-38.

Pesante, D. 1979. A study of the plankton of Laguna Joyuda. M. Sc. Thesis. University of Puerto Rico, Mayagüez, Puerto Rico.

Phinney D.A. \& C.S. Yentsch. 1985. A novel phytoplankton chlorophyll technique: toward automated analysis. J. Plankton Res. 7: 633-642.

Purcell, T.W. 1980. The effects of rainfall runoff on two undeveloped tropical bays in St. John, U.S. Virgin Islands. Caribbean Research Institute, St. Thomas, U.S.Virgin Islands. 47 p.

Reeve, M.R. 1964. Studies on the seasonal variation of the zooplankton in a marine tropical inshore environment Bull. Mar. Sci. 14: 103-122.

Rippingale, R.J. \& E.P. Hodgkin. 1974. Predation effects on the distribution of a copepod. Australian J. Mar. Freshwater Res. 25: 81-91.

Rojas, H.M. \& J.A. Suárez-Caabro. 1979. GuayanillaTallaboa Bays plankton survey. Center for Energy and Environmental Research, Mayagüez, Puerto Rico. 12 p.

Saint-Jean, L. \& M. Pagano. 1990. Night and day variationsin the vertical distribution of zooplankton and net collecting efficiency in Ebrie Lagoon, Ivory Coast. Hydrobiologia 194: 247-265.

Santiago, D. 1988. Temporal patterns of total zooplankton abundances in neritic waters of the northwest coast of Puerto Rico, with notes on the occurrence of Acartia spinata Esterly and A. lilljeborgii Giesbrecht (Copepoda:Calanoidea). M. Sc. Thesis, University of Puerto Rico, Mayagüez, Puerto Rico.

Suárez-Caabro, J.A. \& E.A. Shearls. 1972. Macrozooplankton of Jobos and Guayanilla Bays, Southern
Puerto Rico and its fluctuations under special conditions. Puerto Rico Nuclear Center, Mayagüez, Puerto Rico. 288 p.

Trinast, E.M. 1975. Tidal currents and Acartia distribution in Newport Bay, California. Est. Coastal Mar. Sci. 3: 165-176.

Walter, T.C. 1989. Review of the new world species of Pseudodiaptomus (Copepoda: Calanoidea), with a key to the species. Bull. Mar. Sci. 45: 590-628.

Woodmansee, R.A. 1958. The seasonal distribution of zooplankton off Chicken Bay in Biscayne Bay, Florida. Ecology 39: 247-262.

Wooldridge, T.H. \& T. Erasmus. 1980. Utilization of tidal currents by estuarine zooplankton. Estuar. Coast. Shelf Sci. 11: 107-114.

Wooldridge. T.H. \& C. Bailey. 1982. Estuarine zooplankton of the Sundays Estuary and notes on trophic relationships. South African J. Zool. 17: 151-163.

Yoshioka, P.M., G.P. Owen \& D. Pesante. 1985. Spatial and temporal variations in Caribbean zooplankton near Puerto Rico. J. Plankton Res. 7: 733-751.

Youngbluth, M.J. 1976. Zooplankton populations in a polluted, tropical embayment. Est. Coast. Mar. Sci. 4: 481-496.

Youngbluth, M.J. 1979. The variety and abundance of zooplankton in coastal waters of Puerto Rico. Northeast Gulf Sci. 3: 15-26.

Youngbluth, M.J. 1980. Daily, seasonal and annual fluctuations among zooplankton populations in an unpolluted tropical embayment. Est. Coast. Mar. Sci. 10: 265-287.

Youngbluth, M.J. 1982. Sampling demersal zooplankton: a comparison of field collections using three different emergence traps. J. Exp. Mar. Biol. Ecol. 61: 111-124.

Zayas, J.M. 1979. Some aspects of the ecology of a coastal lagoon. Center for Energy and Environmental Research, Mayagüez, Puerto Rico. 73 p. 